\title{
PRODUCTION AND PURIFICATION OF AN ENDO-1,4- $\beta$-XYLANASE FROM HUMICOLA GRISEA VAR. THERMOIDEA BY ELECTROELUTION
}

\author{
Rubens Monti $^{1 *}$; Leonardo Cardello'; Marcos F. Custódio ${ }^{1}$; Antonio J. Goulart'; Adriana H. Sayama ${ }^{1}$; Jonas Contiero² \\ ${ }^{1}$ Departamento de Alimentos e Nutrição, Faculdade de Ciências Farmacêuticas de Araraquara, Universidade Estadual Paulista, \\ Araraquara, SP, Brasil; ${ }^{2}$ Departamento de Bioquímica e Microbiologia, Instituto de Biociências de Rio Claro, Universidade \\ Estadual Paulista, Rio Claro, SP, Brasil.
}

Submitted: September 03, 2002; Returned to authors for corrections: January 07, 2003; Approved: May 06, 2003

\begin{abstract}
Humicola grisea var. thermoidea produces two forms of extracellular xylanase. The component form 1 was purified using the electroelution method, due to the very small production of this extracellular enzyme. The apparent molecular mass was $61.8 \mathrm{kDa}$ by SDS-PAGE.
\end{abstract}

Key words: electroelution, enzyme purification, extracellular xylanase, Humicola grisea var. thermoidea

\section{INTRODUCTION}

A wild type strain of a thermophilic fungus isolated from Brazilian soil was identified as Humicola grisea var. thermoidea by Monti et al. (8). This stain produces several extracellular enzymes $(3,4,10,15,16)$. Besides cellulose, xylans are the most abundant renewable polysaccharides $(2,5,12)$. Endo- $1,4-\beta-D-$ xylanases (EC 3.2.1.8) are produced by numerous microorganisms and several xylanases from fungus have been purified and biochemically characterized. Purkarthofer et al. (13) suggested that the use of xylanases in pulp and paper industry will probably be one of the major achievements of the biotechnology. Furthermore, Poutanen (11) observed that endogenous and added enzymes have an important effect on the quality of cereal foods. Great progress has been reached due to the result of the studies on xylanolytic enzymes in wheat and germinated wheat.

There are two ways in which macromolecules separated by gel electrophoresis can be purified for further study. The first involves performing electrophoresis in an identical way as that used for purely analytical evaluation and then, once the components of interest have been located, the gel is cut up and the material extracted. The second consists of allowing the components to migrate the whole length of the gel and then collecting them at the end, usually by some suitable elution technique. Some workers refer to only the latter as preparative electrophoresis. Extraction of separated material can be achieved using either stained or unstained gels in three principal ways: simple extraction with an appropriate buffer; solubilization of the gel matrix; electrophoretic elution (1). The aim of the present study was to purify xylanase form 1 from this microorganism by electroelution. This method showed to be efficient for the purification of microbial enzymes up to homogeneity, when they are produced in small amounts.

\section{MATERIALS AND METHODS}

\section{Microorganism}

The fungus was maintained on slants containing $4 \%$ of oatmeal baby food Quaker and solid medium containing $2 \%$ of agar.

\section{Culture media}

The culture media used in this experiment are detailed in Table 1. Corn steep liquor was obtained from Corn Products Brasil. Yeast extract, gelatin and peptone were purchased from Difco Laboratories, U.S.A. All other reagents were of analytical grade.

\footnotetext{
* Corresponding author. Mailing address: Rodovia Araraquara-Jaú, Km 1, Caixa Postal 502. 14801-902, Araraquara, SP, Brasil. Fax: (+5516) 222-0073, E-mail: montiru@fcfar.unesp.br
} 


\section{Enzyme production and culture medium proteins concentration}

Conidia were harvested from a 10-days-old slant and inoculated in $25 \mathrm{~mL}$ of the culture medium. The $\mathrm{pH}$ of the medium was adjusted to 6.0 using $1.0 \mathrm{M} \mathrm{HCl}$. The inoculated medium was incubated in $130 \mathrm{rpm} / \mathrm{min}$ at $40^{\circ} \mathrm{C}$. At specific time intervals the cultures were filtrated through $\mathrm{n}^{\circ} 1$ Whatman paper and treated with Kaolin Sigma $(40 \mathrm{mg} / \mathrm{mL})$. The culture medium proteins were precipitated with $70 \%$ ammonium sulfate and dialyzed overnight to be applied to ion exchange chromatography.

\section{Specific enzymatic activity determination}

Xylanase activities were determined according to Miller's method. Briefly, the enzyme was incubated with $1 \%$ birchwood xylan at $40^{\circ} \mathrm{C}$; samples were removed at specific intervals for quantification of reducing sugar (between 0 to $45 \mathrm{~min}$ ). One unit $(\mathrm{U})$ of xylanase activity was defined as the amount of enzyme required to release reducing sugar at an initial rate of $1.0 \mu \mathrm{mol} . \mathrm{min}^{-1}$ at $40^{\circ} \mathrm{C}$ using xylose as standard. The concentration of soluble proteins were determined according to Hartree (6). The amount of protein was calculated through BSA as standard.

\section{Polyacrylamide gel electrophoresis (PAGE)}

The non-denaturing electrophoresis was carried out as described by Davis ( $\mathrm{pH} \mathrm{8.9,7.5 \%} \mathrm{acrylamide)} \mathrm{and} \mathrm{denaturing}$ conditions according to Laemmli ( $\mathrm{pH} 8.3,12 \%$ acrylamide). To purify the xylanase form 1 from the electrophoresis gels (not stained), the bands were sliced, macerated, centrifuged, dialyzed and assayed to determine which of them presented xylanolytic activity. The gels were stained using $0.5 \%$ Coomassie Brilliant Blue R250 (Sigma). Apparent molecular weight was determined using kit Amersham Pharmacia Biotech (range between 14.6 and $90.0 \mathrm{kDa}$ ).

\section{Ion-exchange chromatography}

Two columns of ion-exchange were used: DEAE-cellulose column $(30 \times 1.1 \mathrm{~cm})$ and DEAE-Trisacryl column $(20 \times 0.8 \mathrm{~cm})$. Both were equilibrated and eluted with $50 \mathrm{mM}$ potassium phosphate buffer $\mathrm{pH} 8.8$ to verify the two forms of xylanase in medium with corncobs. Samples of filtrate of the culture were applied into the first column and fractions of $1.5 \mathrm{~mL}$ were collected with a flow rate of $30 \mathrm{~mL} / \mathrm{h}$ and the samples of proteic band with enzymatic activity obtained from polyacrylamide gels were applied into the second column and fractions of $1.0 \mathrm{~mL}$ were collected with a flow rate of $15 \mathrm{~mL} / \mathrm{h}$.

\section{Electroelution protein purification}

The xylanase form 1 was purified as detailed by Ohshita $e t$ al. (9), using non-denaturing gels instead of denaturing gels. Similar methodology involving electroelution for the purification of a high weight xylanase excreted by a strain of Bacillus $s p$. was described by Sá-Pereira et al. (14).

\section{RESULTS AND DISCUSSION}

\section{Xylanolytic enzyme production}

Humicola grisea var. thermoidea produces and secretes at least two extracellular xylanases. In previous studies, the main xylanolytic component (form 2; $90 \%$ of recovered activity) was purified to homogeneity by Monti et al. (8). The xylanolytic enzymes production by Humicola was studied using the medium described in Table 1. Purkarthofer et al. (13) showed under submerged conditions in shake flasks that carbon and nitrogen sources influenced the enzyme yield. These authors observed that the best xylanase production by T. lanuginosus was found using corncobs (coarse), xylan birchwood and corncobs powder. Kulkarni et al. (7) showed that the main factor for the production of xylanolytic enzymes is the choice of an appropriate inducing substrate and an optimal composition of the medium. In this research, the effect of the medium composition in the extracellular enzyme production at different times was studied for comparative purposes. The data show that there is a significant difference in the enzyme production when different culture medium and sources of xylans were used. According to Monti et al. (8), the maximum production of xylanase activity using larchwood as carbon source was obtained at 24 hours of culture (medium A, Table 1); when birchwood was used in the medium (medium B, Table 1), the xylanase activity $0.542 \pm 0.005$ $\mathrm{U} / \mathrm{mg}$ protein was obtained at 28 hours (Table 2). The substitution of ammonium chloride, yeast extract and peptone by corn steep liquor in the medium (medium C) produced maximum xylanase activity at 22 hours (Fig. 1). These results showed that the composition medium and xylan types had a great influence on the enzyme production (Table 2) and the best medium was the medium C. Furthermore, corncobs is a carbon source of low cost. Fig. 1 shows that the extracellular xylanase activity increases during the growth of the culture, achieving a maximum level at 22 hours and decreasing slowly around 40 hours. The protein determination during the growth of the culture was used because of the difficulties that involve the mycelium separation using this carbon source. That decrease can be explained by the pellets development at 40 hours of growth in corncobs cultures and the enzyme immobilization in those pellets. During

Table 1. Composition of the culture medium used for the production of xylanase form 1 .

\begin{tabular}{cl}
\hline Media & \multicolumn{1}{c}{ Components of the media } \\
\hline A & $0.1 \% \mathrm{CaCO}_{3}, 0.5 \% \mathrm{NaCl}, 0.25 \%$ gelatin, $0.1 \%$ peptone, \\
& $0.8 \%$ yeast extract, $0.2 \% \mathrm{NH}_{4} \mathrm{Cl}, 1 \%$ larchwood \\
B $\quad 0.1 \% \mathrm{CaCO}_{3}, 0.5 \% \mathrm{NaCl}, 0.25 \%$ gelatin, $0.1 \%$ peptone, \\
& $0.8 \%$ yeast extract, $0.2 \% \mathrm{NH}_{4} \mathrm{Cl}, 1 \%$ birchwood \\
$\mathrm{C} \quad$ & $0.1 \% \mathrm{CaCO}_{3}, 0.5 \% \mathrm{NaCl}, 0.25 \%$ gelatin, $0.5 \%$ corn \\
& steep liquor, $1 \%$ powder corncobs \\
\hline
\end{tabular}


the period of 22 hours, there is a drastic decrease of the protein quantity of the initial medium and there is an increase on the protein quantity which is then produced by the microorganism.

\section{Ion exchange chromatography}

To detect the two xylanase forms in the filtrate of the culture containing corncobs (medium $\mathrm{C}$ ), the proteins were precipitated with $70 \%$ ammonium sulfate and dialyzed overnight and applied into a DEAE-cellulose column. Fig. 2 shows that two activity peaks were obtained and labeled as form 1 and form 2 , both eluted in the elution buffer. Xylanase form 2 had previously been purified and characterized by Monti et al. (8).

\section{Purification of xylanase form 1 through electroelution}

The dialyzed sample from medium C (250 mg prot.) was submitted to a preparative non-denaturing 7.5\% PAGE pH 8.9 using glass tubes $13 \times 1.4 \mathrm{~cm}$. Monti et al. (8) determined that xylanase form 2 did not migrate into the $7.5 \%$ PAGE; on the other hand, xylanase form 1 migrated in this gel. After 6 hours at $2 \mathrm{~mA} /$ tube, one of the gels was stained with Coomassie Brilliant Blue R250. After revelation, it was placed side by side with another not stained gel in order to cut the protein bands for the identification of the band with xylanase form 1 activity. The enzyme extracted from the proteic band with activity was applied

Table 2. Effect of the composition of the medium in the production of xylanase form 1 .

\begin{tabular}{crcc}
\hline Media & Protein $(\mathrm{mg} / \mathrm{mL})$ & Xylanase $(\mathrm{U} / \mathrm{mL})$ & Xylanase $(\mathrm{U} / \mathrm{mg})$ \\
\hline A & $2.217 \pm 0.030$ & $1.605 \pm 0.022$ & $0.722 \pm 0.010$ \\
B & $2.58 \pm 0.026$ & $1.385 \pm 0.014$ & $0.542 \pm 0.005$ \\
C & $2.11 \pm 0.046$ & $1.809 \pm 0.040$ & $0.864 \pm 0.019$ \\
\hline
\end{tabular}

Note: Mean values of 3 replicate flasks.

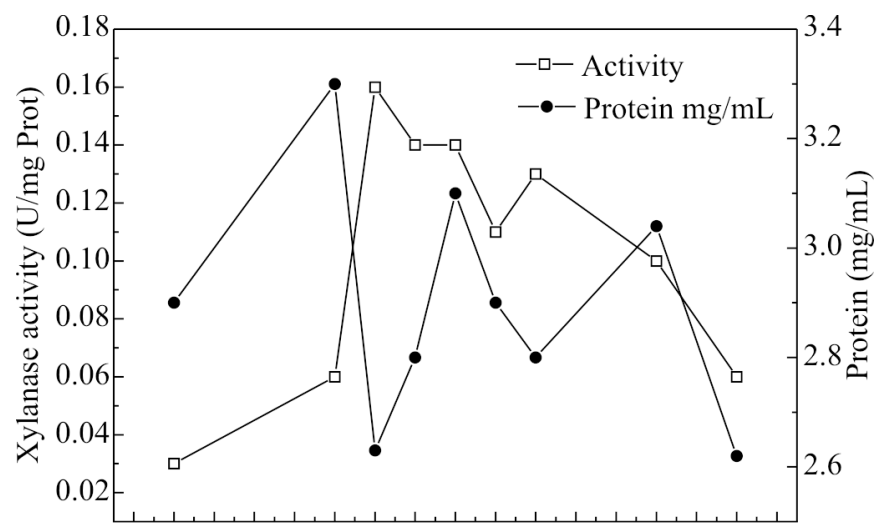

1012141618202224262830323436384042

Time (hours)

Figure 1. Specific activity of xylanase form 1 in function of time of culture in liquid medium C containing $1 \%$ of powder corncobs.

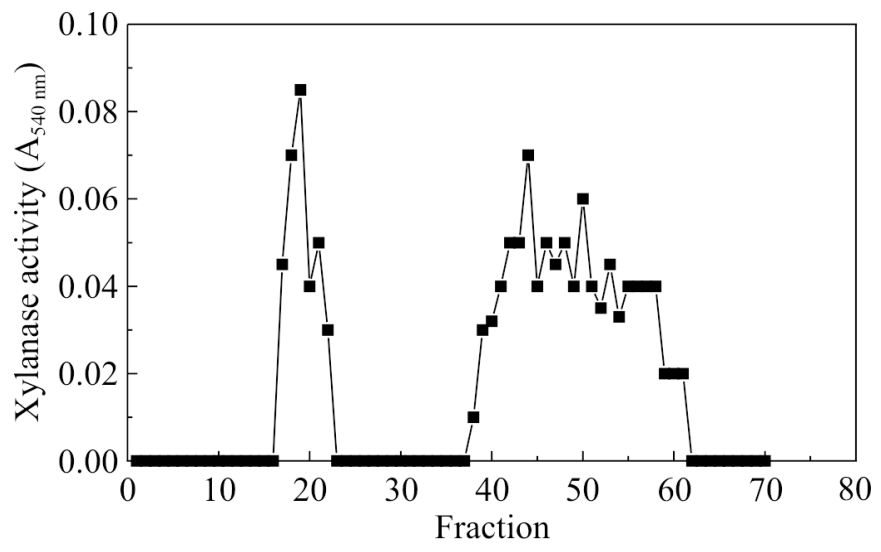

Figure 2. DEAE-cellulose chromatography of ammonium sulfate precipitated protein from the culture with carbon source $1 \%$ corncobs at a flow rate of $30 \mathrm{~mL} / \mathrm{h}$. Fractions of $1.5 \mathrm{~mL}$ were collected and assayed.

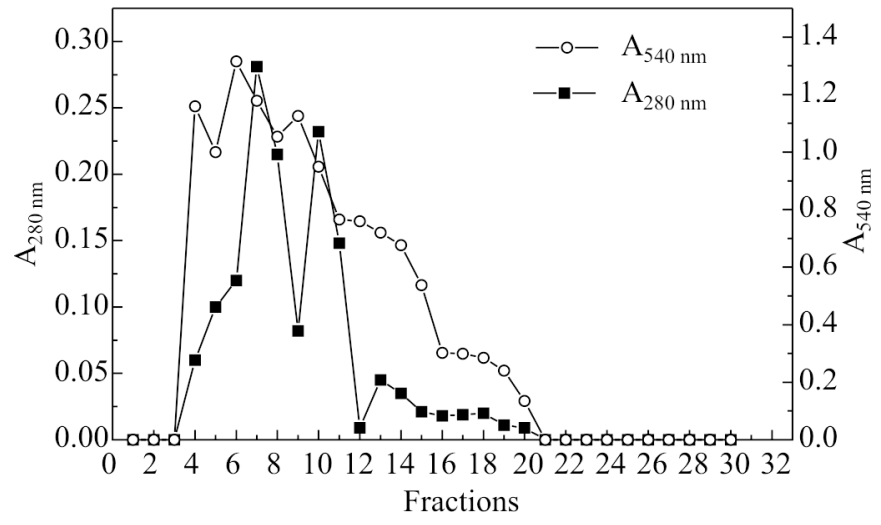

Figure 3. DEAE-Trisacryl chromatography of sliced, macerated and dialyzed polyacrylamide gels eluted with potassium phosphate buffer at a flow rate of $15 \mathrm{~mL} / \mathrm{h}$. Fractions of $1.0 \mathrm{~mL}$ were collected and assayed.

into DEAE-Trisacryl. Figure 3 shows that xylanase form 1 did not bind to the resin and was eluted in the void volume of the equilibrating buffer. To have a greater quantity of form 1 , four similar columns were made and fractions with xylanase form 1 activity were collected, dialyzed and concentrated by vacuum desiccator. The material obtained $\left(2.25 \mathrm{U} / \mathrm{mg}\right.$ prot. $\left.^{-1}\right)$ was put in distilled water and submitted to a non-denaturing 7.5\% PAGE $\mathrm{pH}$ 8.9. After the migration, the band that showed xylanolytic activity obtained of four gels was sliced, macerated, and added to another 5\% PAGE functioning as a heaping up gel to the macerated gels. The protein was extracted electrophoretically. On the side where the migration occurred (bottom of the glass tube) a membrane for dialysis was connected with $5 \mathrm{~mL}$ buffer elution (electroelution). This procedure was performed according 


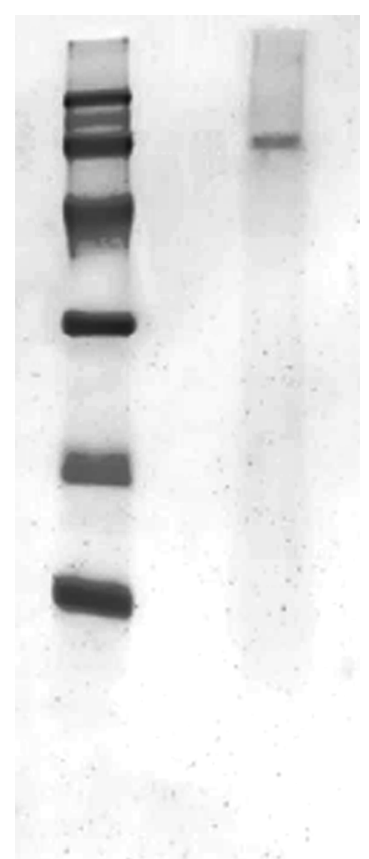

Figure 4. 7\% SDS-PAGE of xylanase form 1. Standard proteins: Phosphorylase b (97 kDa); Bovine serum albunin (66 kDa.); ovalbumin (45 kDa.); Carbonic Anhydrase (30 kDa.); Trypsin Inhibitor Soybean (20.1 kDa); að-Lactalbumin. (14.4 kDa.).

to Ohshita et al. (9). After 6 hours of electrophoretic migration at $10 \mathrm{~mA}$, the protein eluted from the heaping up gel was dialyzed against distilled water. The sample obtained was concentrated by vacuum desiccator, dissolved in $200 \mathrm{ml}$ of water and the enzymatic activity showed the presence of xylanase form 1 . After obtaining the enzyme, it was applied to a 7.5\% PAGE pH 8.9 , where only one proteic band was detected. The apparent molecular mass of purified xylanase form 1 was $61.8 \mathrm{kDa}$ by SDS-PAGE (Fig. 4), suggesting that the preparation was homogeneous and showing that this enzyme was different from form $2(25.5 \mathrm{kDa})$. These results complement what was described by Monti et al. (8), where $H$. grisea produced two forms of xylanase.

\section{CONCLUSIONS}

In this study the best medium for the production of xylanolytic enzymes was composed of $0.1 \% \mathrm{CaCO}_{3}, 0.5 \% \mathrm{NaCl}$, $0.25 \%$ gelatin, $0.5 \%$ corn steep liquor and $1 \%$ powder corncobs (medium C). This media is of low cost and allows the production of both xylanases (form 1 and form 2). The purification of form 1 was exclusively possible through electroelution technique, which allowed its molecular mass determination. It would not have been possible to obtain through other techniques because of the small production of xylanase form 1 . The existence of multiples forms of xylanases has been well described in various researches, but this was the only research that purified the xylanase form 1 produced by Humicola grisea. These results will eventually permit more detailed biochemical characterization and genomic studies.

\section{ACKNOWLEDGEMENTS}

Adriana Hitomi Sayama was supported by Conselho de Desenvolvimento Científico e Tecnológico (CNPq). Rubens Monti was supported by PADC (FCF-Araraquara - UNESP). We thank Osmar Redondo for technical assistance.

\section{RESUMO}

\section{Produção e purificação de uma Endo-1,4- $\beta$-Xilanase de Humicola grisea var. thermoidea por eletroeluição}

Humicola grisea var. thermoidea produz duas formas de xilanase extracelular. A componente forma 1 foi purificada usando o método de eletroeluição devido à baixa produção desta enzima extracelular. A aparente massa molar foi determinada $61,8 \mathrm{kDa}$ por SDS-PAGE.

Palavras-chave: eletroeluição, Humicola grisea var. thermoidea, purificação de enzimas, xilanase extracelular

\section{REFERENCES}

1. Andrews, A.T. Preparative gel electrophoresis. In: Andrews, A.T. Electrophoresis: Theory, techniques, and biochemical and clinical applications. Oxford, New York, 1992, p. 178-204.

2. Biely, P. Microbial xylanolytic system. Trends Biotechnol., 3: 286290, 1985

3. Cardello, L.; Terenzi, H.F.; Jorge, J.A. A cytosolic trehalase from the thermophilic fungus Humicola grisea var. thermoidea. Microbiology, 140: 1671-1677, 1994.

4. Chaves, V.M.G.; Silva, D.O.; Brune, W.; Moreira, M.A. Cellulolytic activities of Humicola sp. Rev. Microbiol., 20: 460-465, 1989.

5. Haltrich, D.; Preiss M.; Steiner, W. Optimization of a culture medium for increased xylanase production by a wild strain of Schizophylum commune. Enzyme Microb. Technol., 15: 854-860, 1993.

6. Hartree, E. F. Determination of protein: a modification of the Lowry method that gives a linear photometric response. Anal. Biochem. v. 48, p. $422-427,1972$.

7. Kulkarni, N.; Shendye, A.; Rao, M. Molecular and biotechnological aspects of xylanases. FEMS Microbiol Rev., 23: 411-456, 1999.

8. Monti, R.; Terenzi, H.F.; Jorge, J.A. Purification and properties of an extracellular xylanase from the thermophilic fungus Humicola grisea var. thermoidea. Can. J. Microbiol., 37: 67581, 1991 .

9. Ohshita, T.; Sakuda, H.; Nakasone, S.; Iwamasa, T. Purification, characterization and subcellular localization of pig liver $\alpha-\mathrm{L}$ iduronidase. Eur. J. Biochem., 179: 201-207, 1989.

10. Peralta, R.M.; Terenzi, H.F.; Jorge, J.A. $\beta$-D-glycosidase activities of Humicola grisea var. thermoidea: biochemical and kinetic characterization of a multifunctional enzyme. Biochim. Biophys. Acta, 1033: 243-249, 1990. 
11. Poutanen, K. Enzymes: An important tool in the improvement of the quality of cereal foods. Trends Food Sci. Technol., 8: 300-306, 1997.

12. Prade, R.A. Xylanases: from Biology to Biotecnology Biotechnol. Genet. Eng. Rev., 13: 100-131, 1995.

13. Purkarthofer, H.; Sinner, M.; Steiner, W. Cellulase-free xylanase from Thermomyces lanuginosus: optimization of production in submerged and solid-stabte culture. Enzyme Microb. Technol., 15: 677-68, 1993.

14. Sá-Pereira, P.; Duarte, J.; Costa-Ferreira, M. Electroelution as a simple and fast protein purification method: isolation of an extracellular xylanase from Bacillus sp. CCMI 966. Enzyme Microb. Technol., 27: 95-99, 2000.

15. Tosil, L.R.O.; Terenzi, H.F.; Jorge, J.A. Purification and characterization of an extracellular gluco-amylase from the thermophilic fungus Humicola grisea var. thermoidea. Can. J. Microbiol., 39: 846-852, 1993.

16. Zimmermann, A.L.S.; Terenzi, H.F.; Jorge, J.A. Purification an properties of extracellular conidial trehalase from Humicola grisea var. thermoidea. Biochim. Biophys. Acta, 1036: 41-46, 1990. 